\title{
Potential of Peptides as Inhibitors and Mimotopes: Selection of Carbohydrate-Mimetic Peptides from Phage Display Libraries
}

\author{
Teruhiko Matsubara \\ Department of Biosciences and Informatics, Faculty of Science and Technology, Keio University, 3-14-1 Hiyoshi, Kouhoku, \\ Yokohama 223-8522, Japan \\ Correspondence should be addressed to Teruhiko Matsubara, matsubara@bio.keio.ac.jp
}

Received 1 June 2012; Revised 31 July 2012; Accepted 2 August 2012

Academic Editor: Hiroshi Murakami

Copyright ( $(2012$ Teruhiko Matsubara. This is an open access article distributed under the Creative Commons Attribution License, which permits unrestricted use, distribution, and reproduction in any medium, provided the original work is properly cited.

\begin{abstract}
Glycoconjugates play various roles in biological processes. In particular, oligosaccharides on the surface of animal cells are involved in virus infection and cell-cell communication. Inhibitors of carbohydrate-protein interactions are potential antiviral drugs. Several anti-influenza drugs such as oseltamivir and zanamivir are derivatives of sialic acid, which inhibits neuraminidase. However, it is very difficult to prepare a diverse range of sugar derivatives by chemical synthesis or by the isolation of natural products. In addition, the pathogenic capsular polysaccharides of bacteria are carbohydrate antigens, for which a safe and efficacious method of vaccination is required. Phage-display technology has been improved to enable the identification of peptides that bind to carbohydrate-binding proteins, such as lectins and antibodies, from a large repertoire of peptide sequences. These peptides are known as "carbohydrate-mimetic peptides (CMPs)" because they mimic carbohydrate structures. Compared to carbohydrate derivatives, it is easy to prepare mono- and multivalent peptides and then to modify them to create various derivatives. Such mimetic peptides are available as peptide inhibitors of carbohydrate-protein interactions and peptide mimotopes that are conjugated with adjuvant for vaccination.
\end{abstract}

\section{Introduction}

A variety of glycoconjugate carbohydrate structures on the cell surface are important for biological events [1]. Carbohydrate structures on the cell surface change according to cell status, for example, during development, differentiation, and malignant alteration. Several glycoconjugates, including stage-specific embryonic antigen (SSEA)-3, SSEA-4, and tumor-rejection antigen (TRA)-1-60, are used as molecular makers of pluripotency to control the quality of induced pluripotent stem (iPS) cells [2]. Carbohydrateprotein interactions are the first cell surface events in cell-cell communication, following which processes such as infection and signal transduction occur. However, the reasons for the changes in carbohydrate structures on the cell surface are not clear. In addition, most receptors for glycoconjugates have not been identified. To investigate the biological roles of carbohydrates, sets of carbohydrates and their corresponding carbohydrate-binding proteins are required.
Carbohydrate-binding proteins such as plant lectins, bacterial toxins, and anticarbohydrate antibodies are available for studying carbohydrate-protein interactions $[3,4]$. However, the repertoire of carbohydrate structures recognized by these proteins is limited and insufficient to cover the majority of structures. In addition, because carbohydrates are ubiquitous components of cell membranes and bio(macro)molecules, the immune response stimulated by glycoconjugates is negligible $[5,6]$, that is, high affinity carbohydrate-specific IgG-isotype antibodies are not easily obtained. Even if anticarbohydrate antibodies are generated, IgG comprises no more than $28 \%$ of the antibodies (74 IgGs in a total of 268 antibodies, with the remainder being IgMs) [7]. Therefore, while anticarbohydrate antibodies of the IgG isotype are preferred for carbohydrate research, IgMantibodies with low affinity have been often used. Moreover, obtaining pure and homogeneous carbohydrates (or glycoconjugates) is very difficult. This is because regioselective protection of the hydroxy groups of the monosaccharide is 
required. Programmable one-pot oligosaccharide synthesis is widely performed using protected monosaccharides and/or oligosaccharides [8-10]. Enzyme-catalyzed oligosaccharide synthesis has been also developed [10-12]. Several oligosaccharides such as KH-1 antigen (nonasaccharide of $\mathrm{Le}^{\mathrm{Y}}-\mathrm{Le}^{\mathrm{X}}$ ), globo-H hexasaccharide, and the core pentamannosides have been prepared by automated solid-phase oligosaccharide synthesis [8]. However, due to the complicated procedures of carbohydrate preparation, a general methodology for their chemical synthesis is not yet established.

To compensate for the lack of synthetic carbohydrates and to overcome their inherent weak immunogenicity, short peptides that bind to carbohydrate-binding proteins have been identified from phage-display libraries (Figure 1). These peptides mimic carbohydrate structures [13] and are called "carbohydrate-mimetic peptides (CMPs)" or "peptide mimotopes." It is predicted that CMPs, as well as carbohydrates, are recognized by carbohydrate-binding proteins. Small molecules such as biotin and carbohydrate mimotope (Glycotope) mimicking peptides have been frequently identified, and a number of reviews focusing on different aspects of their properties and uses have been published [14-16]. In this paper, recent studies on the selection and application of CMPs are surveyed and summarized according to the classification of target carbohydrate-binding proteins.

\section{Peptide Selection from Phage Display Libraries}

Phage display is an efficient selection (and screening) system for the identification of target-specific peptides and proteins from a large number of candidates [20-22]. A filamentous virus (M13 and fd, etc.) that infects E. coli is frequently used in phage display technology. When DNA encoding foreign sequences is inserted into the coat protein (pIII or pVIII) region in the virus genome (M13 phage vector, etc.), the corresponding sequence is fused with the coat protein of the viral particle (Figure 2(a)) [20]. The foreign sequence is "displayed" on the viral particle and is able to interact with various types of target molecules.

In the case of peptide libraries, the length of the peptides is often 5-20 amino acids. There are two types of peptide library: linear peptide libraries and cyclic peptide libraries (Figure 2(b)). The randomized region of cyclic peptide libraries is surrounded by two cysteines (e.g., $\mathrm{CX}_{7} \mathrm{C}$ ) to restrict the peptide conformation via disulfide bonds. The diversity of a peptide library is often $10^{8}-10^{9}$, which is sufficient to cover a combination of hexapeptide libraries $\left(\mathrm{X}_{6} ; 20^{6}=6.4 \times 10^{7}\right)$. Several kinds of peptide libraries (e.g., Ph.D. Phage Display Peptide Library Kits, New England Biolabs) and customizable phage vectors (Ph.D. Peptide Display Cloning System) are commercially available.

To isolate phage clones that have high affinity for a target molecule, a set of procedures called "affinity selection (biopanning)" is performed (Figure 2(c)). First, the target molecule is incubated with the phage library in order to bind to specific peptide sequences. After removal of excess phages by washing, the bound phages are eluted by incubation with a known ligand for the target or an acidic buffer. The phages are amplified by infection of hosts ( $E$. coli), and the phage pool is subjected to another round of biopanning. By repeating these steps, target-binding phages are enriched, and, finally, phage clones are obtained. The peptides with high affinity for the target molecule are identified by DNA sequencing of individual phage clones. Huang and coworkers established a mimotope database MimoDB (http://immunet.cn/mimodb/) that contains the results of biopanning experiments including the phage libraries used and the peptide sequences identified $[23,24]$. This database will help in the development of therapeutic molecules and the identification of superior peptide mimotopes for vaccination.

\section{CMPs against Lectins}

3.1. Monosaccharide-Mimetic Peptides. Most lectins recognize monosaccharides and disaccharides [4]. Concanavalin A (ConA) is a lectin from jack-bean (Canavalia ensiformis) that binds to $\alpha$-mannose $(\alpha$-Man) and $\alpha$-glucose $(\alpha$-Glc). ConA is a famous lectin that is commercially available for the biological investigation of glycoconjugates. The first CMPs were selected from a random peptide library against ConA simultaneously by Oldenburg et al. (octapeptide library) [25] and Scott et al. (hexapeptide library) [13] (Table 1). Peptides containing the consensus sequence, Tyr-Pro-Tyr (YPY), showed high affinity for ConA with a dissociation constant $\left(K_{\mathrm{d}}\right)$ of $46 \mu \mathrm{M}$, and the $K_{\mathrm{d}}$ for methyl $\alpha$-Man was $89 \mu \mathrm{M}$. The peptides are considered to mimic the structure of carbohydrates because the ConA-peptide interaction was inhibited by $\alpha$-Man.

To obtain Man/Glc-mimetic peptides, Yu et al. used three lectins, including ConA, Lens culinaris agglutinin (LCA) from lentil, and Pisum sativum agglutinin (PSA) from pea [31]. Two cyclic peptides, CNTPLTSRC and CSRILTAAC, were selected from a cyclic heptapeptide library, but these peptides did not contain the YPY motif. Docking simulation of the peptide-lectin interaction suggested that the cyclic peptides bound to an alternative binding site, not to the sugar-binding site that is recognized by YPY-containing peptides. In another screen using monosaccharide-binding lectins, Eggink and Hoober identified a GalNAc/Gal-mimetic dodecapeptide, VQATQSNQHTPR, that was selected against Helix pomatia (HPA) lectin [32]. A tetrameric dendrimer of the peptide, $\left[(\text { VQATQSNQHTPR })_{2} \mathrm{~K}\right]_{2} \mathrm{~K}$, was synthesized chemically (Figure 3 ), which was shown to stimulate the secretion of interleukin (IL)-8 and IL-21 from human peripheral blood mononuclear cells (PBMCs).

3.2. Disaccharide-Mimetic Peptides. The Gal 1 1-3Gal disaccharide is recognized by Griffonia simplicifolia I-B4 (GSI-B4) and Bandeiraea simplicifolia isolectin B4 (BS-I-B4) (Figure 4). The Gal $\alpha 1-3 \mathrm{Gal}$ structure is a major carbohydrate antigen recognized by human anti-pig antibodies, and inhibitors of human natural antibodies may be useful in pigto-human xenotransplantation. Kooyman et al. identified a peptide sequence, SSLRGF, that binds to GS-I-B4 lectin 


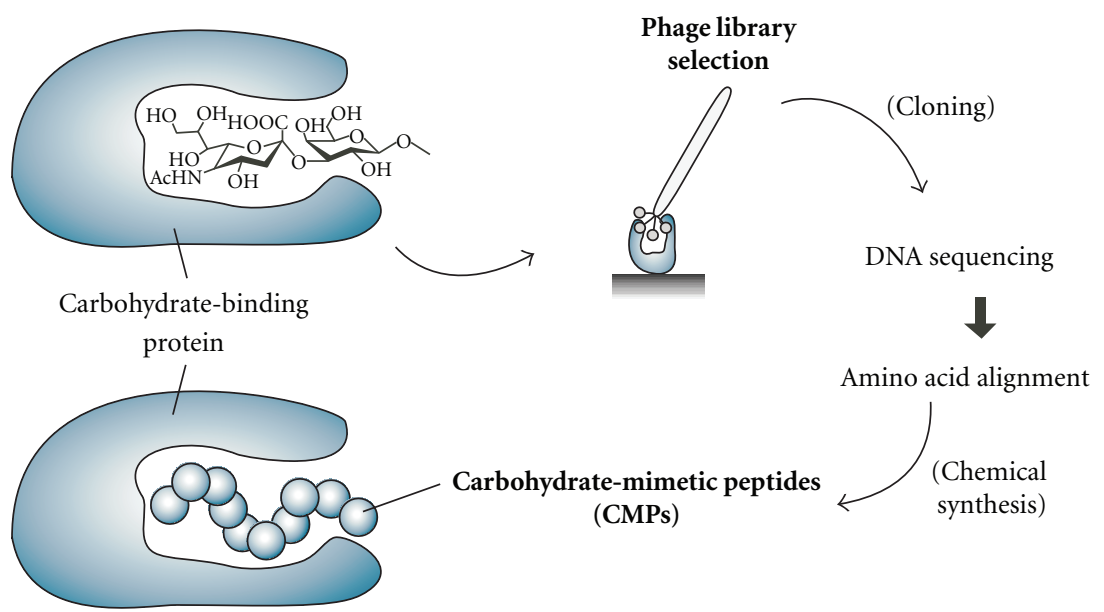

FIGURE 1: Identification of carbohydrate-mimetic peptides (CMPs) by affinity selection from a phage-display library. Selection is performed against carbohydrate-binding proteins. The peptides identified are chemically synthesized and recognized by the carbohydrate-binding protein.

\section{Phage-display system}

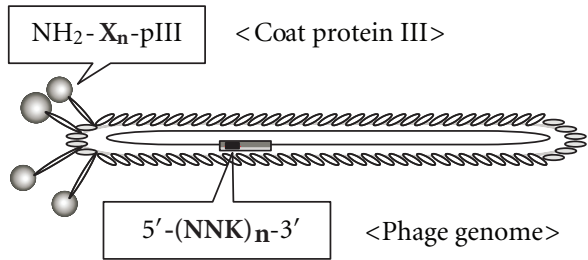

(a)

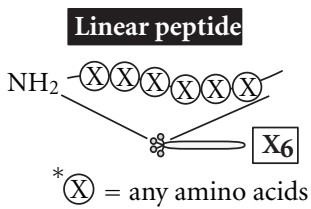

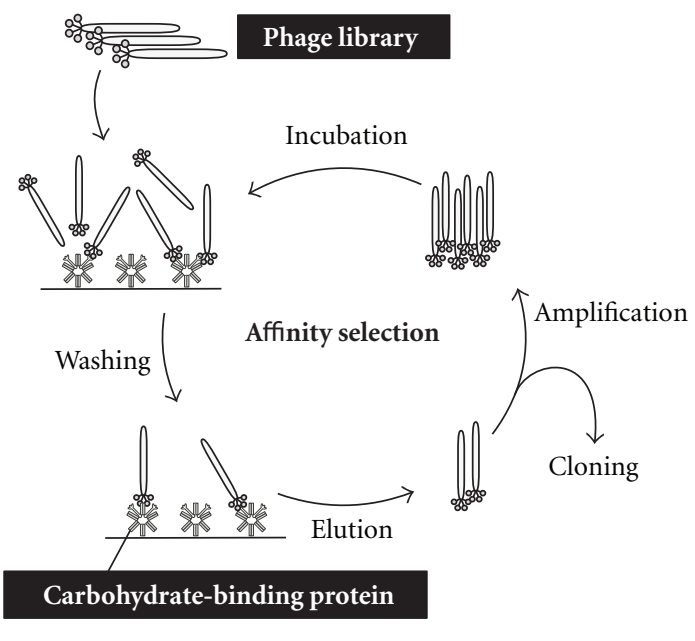

(c)

FIgURE 2: Phage-display system for affinity selection. (a) A typical filamentous phage carrying a peptide library. Foreign peptides $\left(\mathrm{X}_{n}\right)$ are displayed on the N-terminus of coat protein III (pIII) (type 3; M13 or fd phage). An oligonucleotide coding peptide library [-(NNK) $\left.n^{-}\right]$is inserted into the phage genome. $\mathrm{X}=$ any amino acid; $\mathrm{N}=\mathrm{A}, \mathrm{C}, \mathrm{G}$, or T; $\mathrm{K}=\mathrm{G}$ or T. (b) Linear (hexamer, left) and cyclic (heptamer, right) peptide libraries. (c) Schematic representation of the procedure for affinity selection (biopanning). The phage library is incubated with target receptors (carbohydrate-binding proteins), and unbound phages are removed by washing. Bound phages are eluted, amplified in E. coli, and subjected to the next cycle of biopanning. The cycle is repeated several times to enrich target-specific phages. Individual enriched phages are isolated and used for DNA sequencing.

from a hexapeptide library [27]. Zhan et al. identified a peptide, NCVSPYWCEPLAPSARA, by selection with BS-IB4 lectin [28]. These peptides, SSLRGF and NCVSPYWCEPLAPSARA, inhibited the agglutination of pig red blood cells (RBCs) by human serum. Two peptides, FHENWPS and FHEFWPT, that inhibit the agglutination of RBCs were identified by selection against anti-Gal antibody by Lang et al. [42]. However, the peptides identified from three selections contained no obvious consensus sequence.

Influenza virus hemagglutinin (HA) recognizes sialylgalactose structures (Neu5Ac-Gal) in glycoproteins and glycolipids on the cell surface in the initial stage of the infection process (Figure 4). Matsubara et al. identified CMPs from a pentadecapeptide library by selection with HAs of the $\mathrm{H} 1$ and $\mathrm{H} 3$ subtypes [17]. A HA-binding peptide, ARLSPTMVHPNGAQP, was identified from the first selection, and mutational sublibraries were prepared. A secondary selection was performed to improve the binding affinity for HAs, and the peptide was matured to peptide s2, ARLPRTMVHPKPAQP. The peptide was modified with a stearoyl group, and a molecular assembly of the alkylated peptides inhibited the infection of Madin-Darby 


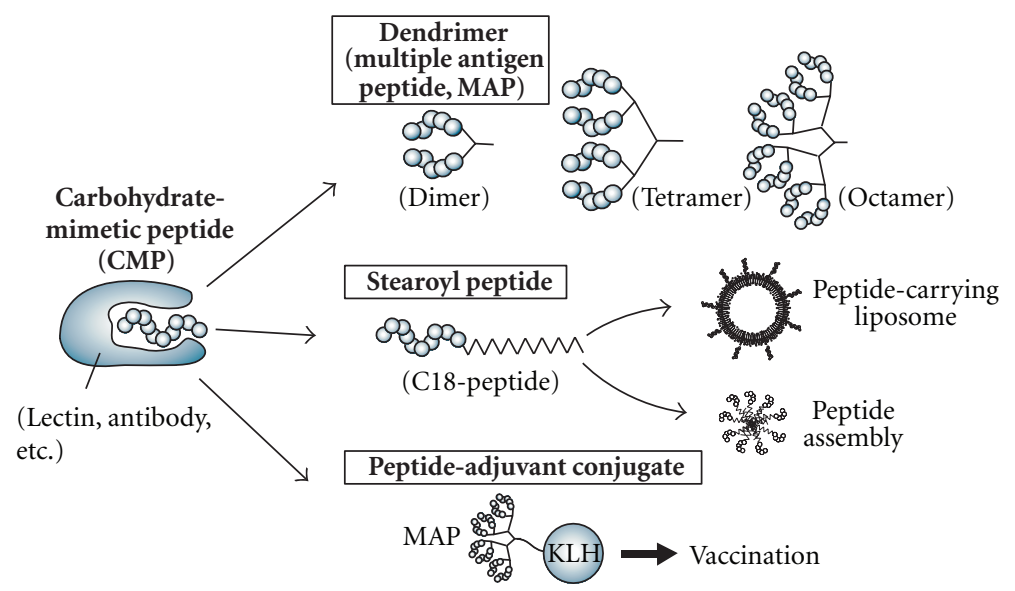

FIGURE 3: Representative chemical modifications of CMPs. To enhance the binding affinity, multiple CMPs are synthesized to give dimeric, tetrameric, and octameric dendrimers (multiple antigen peptide; MAP) (upper). The dendrimers are further conjugated with biotin, fluorescence groups, or adjuvants for vaccination. The peptide is modified with an alkyl group (stearic acid), enabling the peptide lipid to be incorporated into liposomes or to undergo self-assembly (middle). Monomeric CMP or CMP dendrimers are conjugated with adjuvants such as keyhole limpet hemocyanin (KLH), QS-21, and so forth (lower). The peptide-adjuvant conjugate is vaccinated into animals.

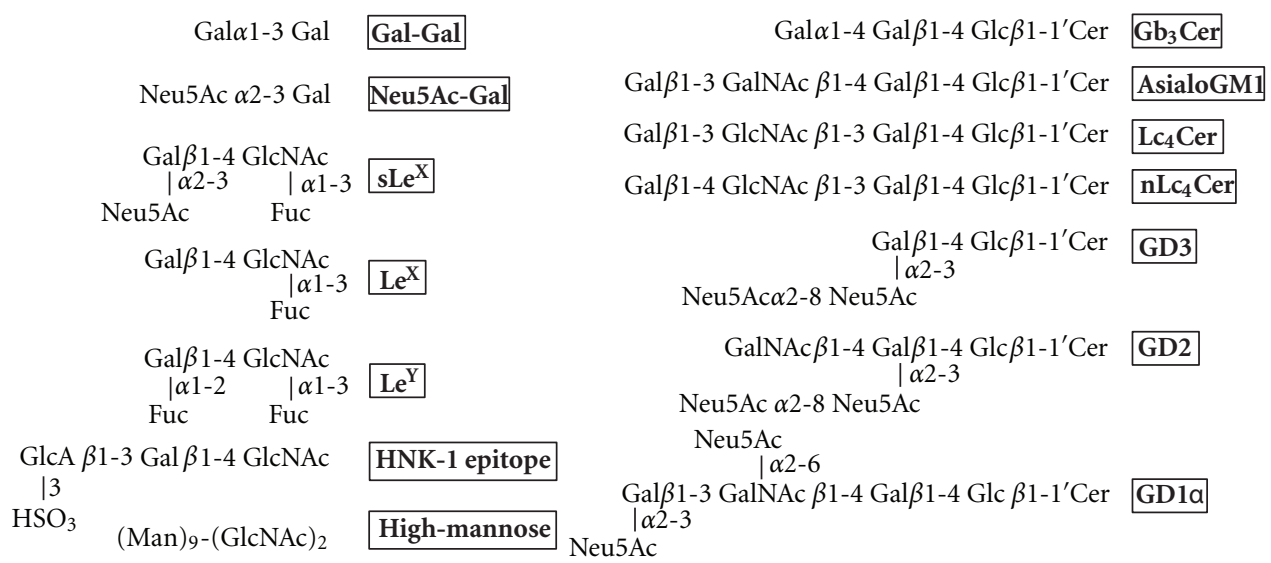

FIGURE 4: Oligosaccharide structures of carbohydrate antigens that are mimicked by peptides.

canine kidney cells by influenza virus (Figure 3). Finally, a pentapeptide fragment from the $\mathrm{N}$-terminal of s2, ARLPR [s2(1-5)], was found to show the highest inhibitory activity. A docking study of the interaction between the peptide s2(1-5) and HA suggested that the peptide is recognized by the Neu5Ac-Gal receptor-binding pocket (Figure 5(a)). The figure indicates that three side chains of H3HA (Ser 136, Asn137, and Glu190) have the potential to interact with the peptide instead of Neu5Ac, and hydrophobic residues (Leu194, Leu226, and Trp222) are close to the peptide (Figure 5(b)).

\section{CMPs against Oligosaccharide-Binding Antibodies}

4.1. Oligosaccharide-Mimetic Peptides for Inhibition. Glycoproteins and glycosphingolipids have unique oligosaccharide structures at their nonreducing termini [1]. Cell-cell communication is performed by oligosaccharides that are recognized by families of cell adhesion proteins such as selectins and sialic acid-binding immunoglobulin- (Ig-) like lectins (siglecs). Pathogenic viruses, toxins, and bacteria also recognize oligosaccharide structures [3]. Because an abundant variety of oligosaccharide structures relates to many carbohydrate-protein interactions, oligosaccharide-mimetic peptides mediate many kinds of inhibitory activities.

The sialyl-Lewis ${ }^{\mathrm{X}}\left(\mathrm{sLe}^{\mathrm{X}}\right)$ structure, Neu5Ac $\alpha 2-3 \mathrm{Gal} \beta 1$ 4 (Fuc $\alpha 1-3)$ GlcNAc, is recognized by E-selectin and is a famous carbohydrate antigen (Figure 4). sLe $\mathrm{X}^{\mathrm{X}}$-mimetic peptides were identified by selection against E-selectin $[29,30]$ and anti-sLe ${ }^{\mathrm{X}}$ antibody [36] (Tables 1 and 2). Martens et al. identified the HITWDQLWNVMN peptide and further optimized the sequence as DITWDQLWDLMK using a mutagenesis library [29]. The binding affinity of the synthetic peptide for E-selectin was improved 100 -fold by this optimization $\left(\mathrm{IC}_{50}\right.$ for $\mathrm{sLe}^{\mathrm{X}}$ binding to E-selectin; from $420 \mathrm{nM}$ to $4 \mathrm{nM}$ ). The DITWDQLWDLMK peptide inhibited 

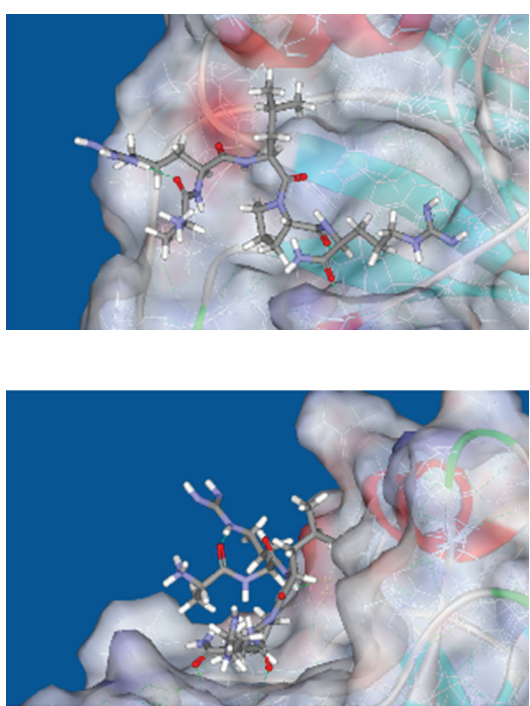

(a)

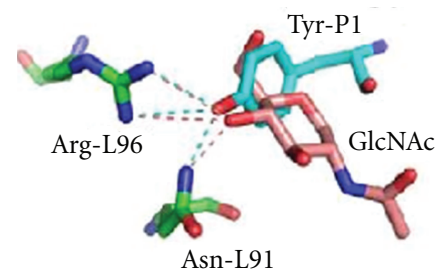

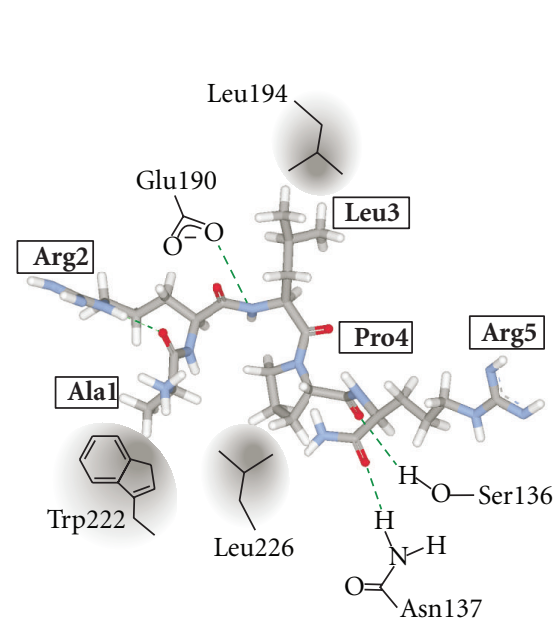

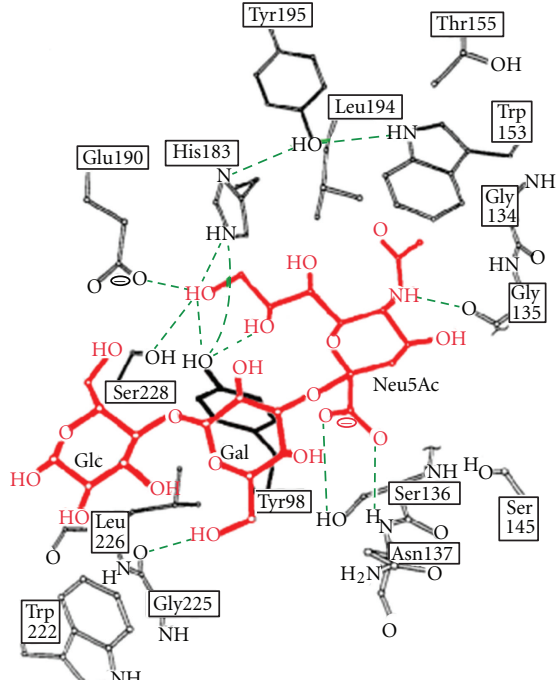

(b)

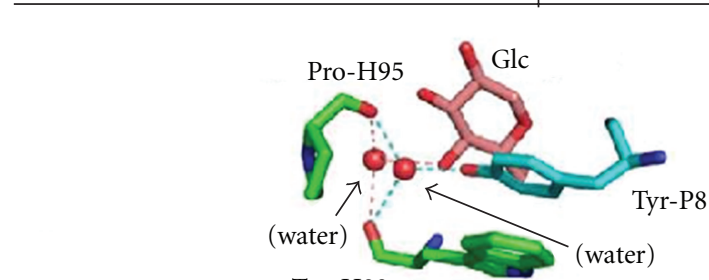

Trp-H33
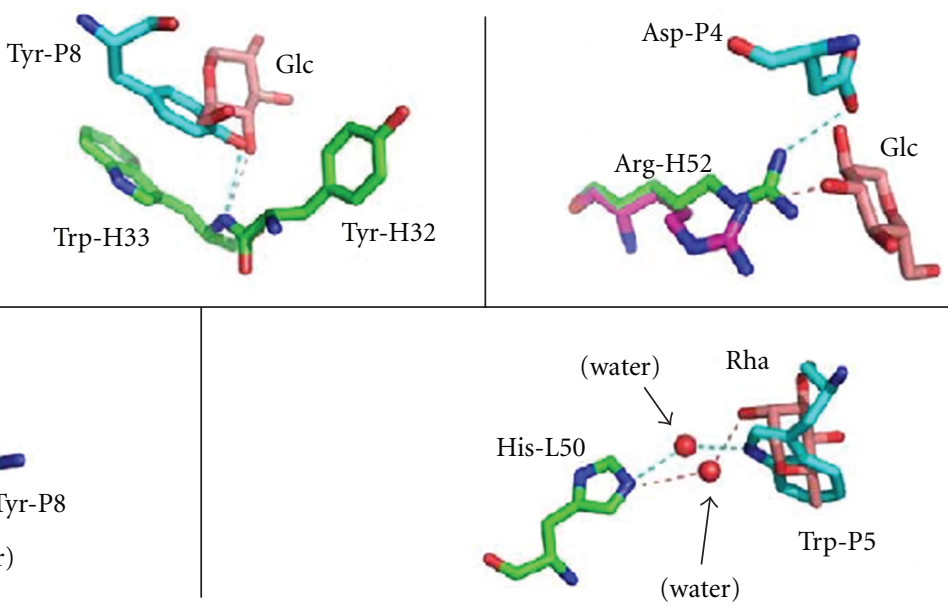

(c)

Figure 5: (a) Computer simulation of the interaction between peptide s2(1-5) and HA. A docking pose of the s2(1-5)-HA complex (left) and schematic diagram of the binding site of HA (right). The peptide is thought to be recognized by the Neu5Ac-Gal receptor-binding pocket. The peptide is shown as a stick model. Three potential hydrogen bonds (green dotted lines) between $\mathrm{H} 3$ and s2(1-5) are proposed (Glu190-Leu3, Ser136-Pro4, and Asn137-Arg5), which are similar to those in H3-Neu5Ac. Adapted from reference [17]. (b) Schematic diagram of the binding site of H3HA (Protein Data Bank entry, 1HGG). Neu5Ac $\alpha 2-3$ Gal-Glc (sialyllactose) is shown in red. Modified from [18]. (c) Comparison of the polar interactions shown in the oligosaccharide ( $O$-antigen of $S$. flexneri serotype $2 \mathrm{a})$ and peptide B1 (YLEDWIKYNNQK) complexes of monoclonal antibody F22-4. The peptide and oligosaccharide ligands are distinguished by carbon atoms shown in cyan and pink, respectively ( $\mathrm{P}$, peptide; Rha, rhamnose). The carbon atoms of the F22-4 residues are shown in green ( $\mathrm{H}$, heavy chain; L, light chain). Adapted from [19].

the adhesion of HL-60 cells and reduced neutrophil rolling on lipopolysaccharide- (LPS-) stimulated human umbilical vein endothelial cells. Qiu et al. designed WRY-containing peptides from the sLe ${ }^{\mathrm{X}}$-mimetic peptide sequences, but these peptides cross-reacted with anti-Lewis ${ }^{\mathrm{Y}}$ antibody. Octameric multiple antigen peptides (MAPs) were conjugated with QS-21 adjuvant, which resulted in cytotoxic IgM and IgG antibodies (Figures 3 and 6). MAPs, in which peptides are attached to an octabranched amino acid backbone, are used to generate antibodies against a synthetic peptide, which is useful for the design of vaccines [94]. Katagihallimath et al. selected a cyclic CSRLNYLHC peptide against anti-Le ${ }^{\mathrm{X}}$ antibody [37]. The trisaccharide Le ${ }^{\mathrm{X}}$ structure is known as CD15 or SSEA-1, and this structure is expressed in the developing and adult murine central nervous system. The $\mathrm{Le}^{\mathrm{X}}$ mimetic peptide inhibited CD24-induced neurite outgrowth.

Neutral glycosphingolipid $\mathrm{Lc}_{4} \mathrm{Cer}$-mimetic peptides showed unique activity [46] (Table 3 ). Lc $\mathrm{Lc}_{4}$ Cer contains Gal $\beta 1-3 \mathrm{GlcNAc} \beta 1-3 \mathrm{Gal} \beta 1-4 \mathrm{Glc}$ tetrasaccharide that is linked to ceramide (Figure 4 ), and Jack bean $\beta$-galactosidase digests a nonreducing terminus $\beta$-Gal to give $\mathrm{Lc}_{3} \mathrm{Cer}$. The $\mathrm{Lc}_{4}$ Cer-mimetic peptides inhibited digestion by 


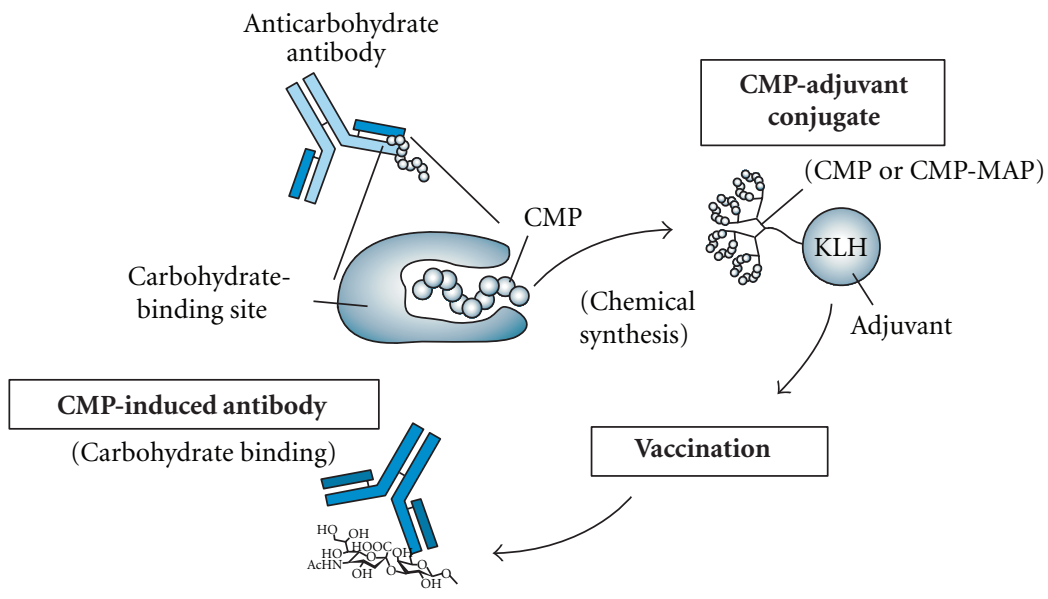

FIgure 6: Procedure for obtaining CMP-induced antibodies by vaccination. A peptide mimotope (CMP) is conjugated with an adjuvant such as KLH and used for vaccination.

TABLE 1: Summary of the selection of CMPs with lectins.

\begin{tabular}{|c|c|c|c|c|c|}
\hline $\begin{array}{l}\text { Target lectins } \\
\text { (abbreviations) }\end{array}$ & $\begin{array}{l}\text { Peptide } \\
\text { library }\end{array}$ & $\begin{array}{l}\text { Peptide motif or } \\
\text { representative sequences } \\
\text { (peptide name) }\end{array}$ & $\begin{array}{c}\text { Lectin-binding } \\
\text { carbohydrate structures }\end{array}$ & References & Notes* \\
\hline Concanavalin A (ConA) & $\mathrm{X}_{8}, \mathrm{X}_{6}$ & YPY motif & Man; Glc & $\begin{array}{c}{[13,25,} \\
26]\end{array}$ & Inhibition of Man binding \\
\hline $\begin{array}{l}\text { Griffonia simplicifolia } \\
\text { I-B4 isolectin (GS-I-B4) }\end{array}$ & $\mathrm{X}_{6}$ & SSLRGF & Gal $\alpha 1-3 \mathrm{Gal}$ & {$[27]$} & $\begin{array}{l}\text { Inhibition of RBC } \\
\text { agglutination }\end{array}$ \\
\hline $\begin{array}{l}\text { Bandeiraea simplicifolia } \\
\text { I-B4 isolectin (BS-I-B4) }\end{array}$ & $\mathrm{XCX}_{15}$ & NCVSPYWCEPLAPSARA & Gal $\alpha 1-3 \mathrm{Gal}$ & {$[28]$} & $\begin{array}{l}\text { Inhibition of RBC } \\
\text { agglutination }\end{array}$ \\
\hline \multirow[t]{2}{*}{ E-selectin } & $\mathrm{X}_{12}$ & DITWDQLWDLMK & $\begin{array}{c}\text { Sialyl Lewis }{ }^{\mathrm{X}} \\
{[\text { Neu5Ac } \alpha 2-3 \mathrm{Gal} \beta 1-} \\
4(\text { Fuc } \alpha 1-3) \text { GlcNAc] }\end{array}$ & [29] & $\begin{array}{l}\text { Inhibition of cell adhesion, } \\
\text { reduction of neutrophil } \\
\text { rolling, and so forth }\end{array}$ \\
\hline & $\mathrm{X}_{7}$ & IELLQAR & & {$[30]$} & $\begin{array}{l}\text { Octameric MAP, inhibition } \\
\text { of HL-60, and B16 cell } \\
\text { adhesion }\end{array}$ \\
\hline $\begin{array}{l}\text { Concanavalin A (ConA); } \\
\text { Lens culinaris agglutinin } \\
\text { (LCA); Pisum sativum } \\
\text { agglutinin (PSA) }\end{array}$ & $\mathrm{X}_{12}, \mathrm{CX}_{7} \mathrm{C}$ & CNTPLTSRC; CSRILTAAC & Man; Glc & {$[31]$} & $\begin{array}{l}\text { Inhibition of Man binding; } \\
\text { docking study }\end{array}$ \\
\hline $\begin{array}{l}\text { Lectin from Helix } \\
\text { pomatia (HPA) }\end{array}$ & $\mathrm{X}_{12}$ & VQATQSNQHTPRGGGS & $\begin{array}{c}\text { O-linked } \alpha \text {-GalNAc; } \\
\text { Gal } \beta 1 \text {-3GalNAc; } \\
\alpha \text {-GlcNAc }\end{array}$ & {$[32]$} & $\begin{array}{l}\text { Tetrameric dendrimer, } \\
\text { stimulation of IL- } 8 \text {, and } \\
\text { IL-21 secretion }\end{array}$ \\
\hline $\begin{array}{l}\text { Lipopolysaccharide } \\
\text { (LPS) binding protein } \\
\text { (LBP); CD14 }\end{array}$ & $\mathrm{X}_{12}$ & FHRWPTWPLPSP (MP12) & Lipopolysaccharide & {$[33]$} & $\begin{array}{l}\text { Inhibition of LPS-induced } \\
\text { INF- } \alpha \text { expression }\end{array}$ \\
\hline $\begin{array}{l}\text { Influenza virus } \\
\text { hemagglutinin (HA) }\end{array}$ & $\mathrm{X}_{15}$ & $\begin{array}{l}\text { ARLPRTMVHPKPAQP } \\
(\mathrm{s} 2) ; \text { ARLPR [s2(1-5)] }\end{array}$ & Neu5Ac $\alpha 2-3 \mathrm{Gal}$ & {$[17]$} & $\begin{array}{l}N \text {-stearoyl peptide; } \\
\text { inhibition of flu infection }\end{array}$ \\
\hline
\end{tabular}

*RBC: red blood cell; IL: interleukin; INF: interferon.

$\beta$-galactosidase at a high concentration of enzyme, whereas the peptides enhanced the digestion of $\mathrm{Lc}_{4} \mathrm{Cer}$ at lower concentration of enzyme. This unique activity of the peptides was also shown in the digestion of $\mathrm{nLc}_{4}$ Cer. This group also identified WHW-containing peptides such as WHWRHRIPLQLAAGR by selection with anti-GD1 $\alpha$ antibody [47]. The ganglioside GD1 $\alpha$ is cell adhesion molecule of murine metastatic large cell lymphoma (RAW117-H10 cells) that binds to endothelial cells. GD1 $\alpha$-mimetic peptides inhibited the adhesion between RAW 117-H10 cells and hepatic sinusoidal endothelial (HSE) cells. Furthermore, the metastasis of RAW117-H10 cells to 


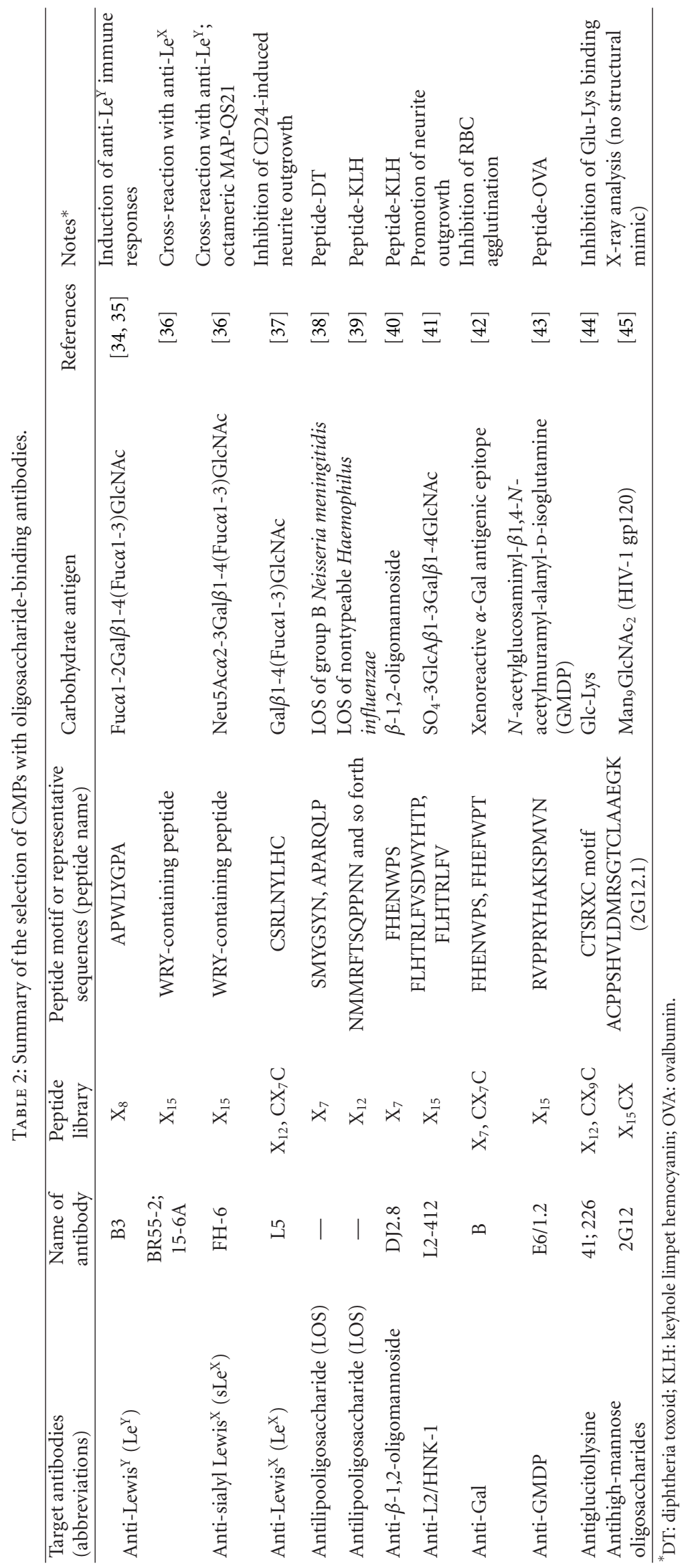




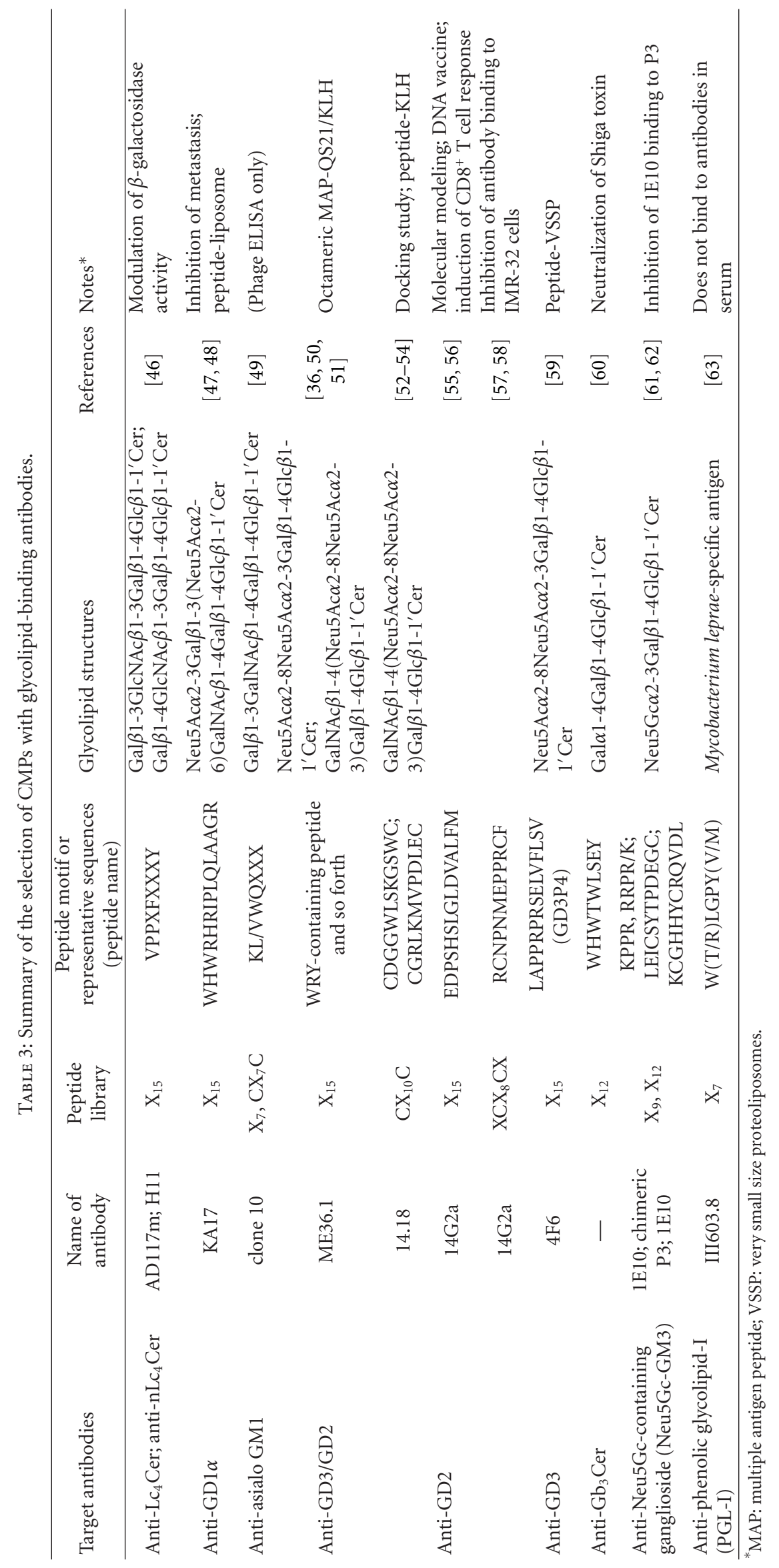




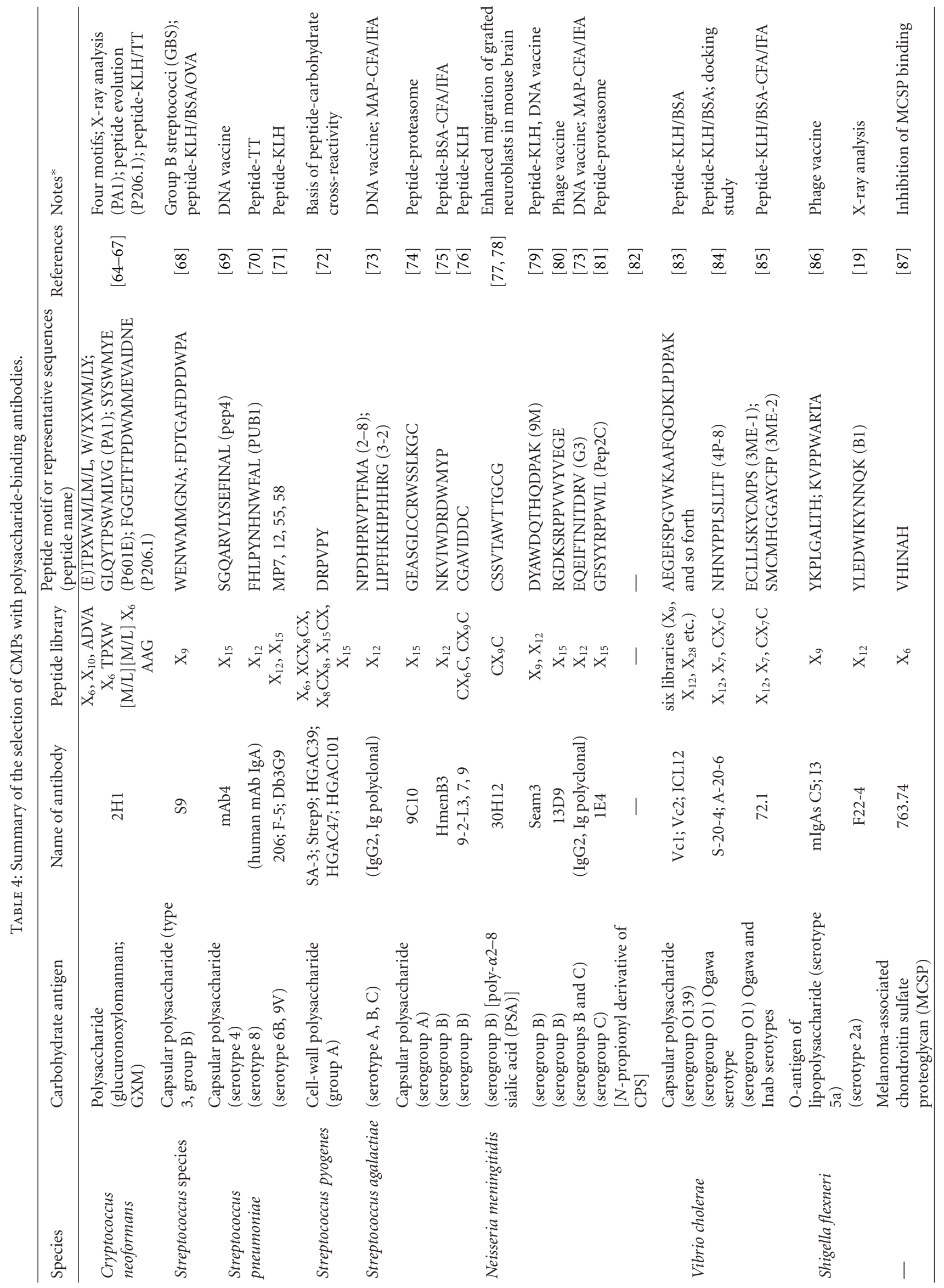




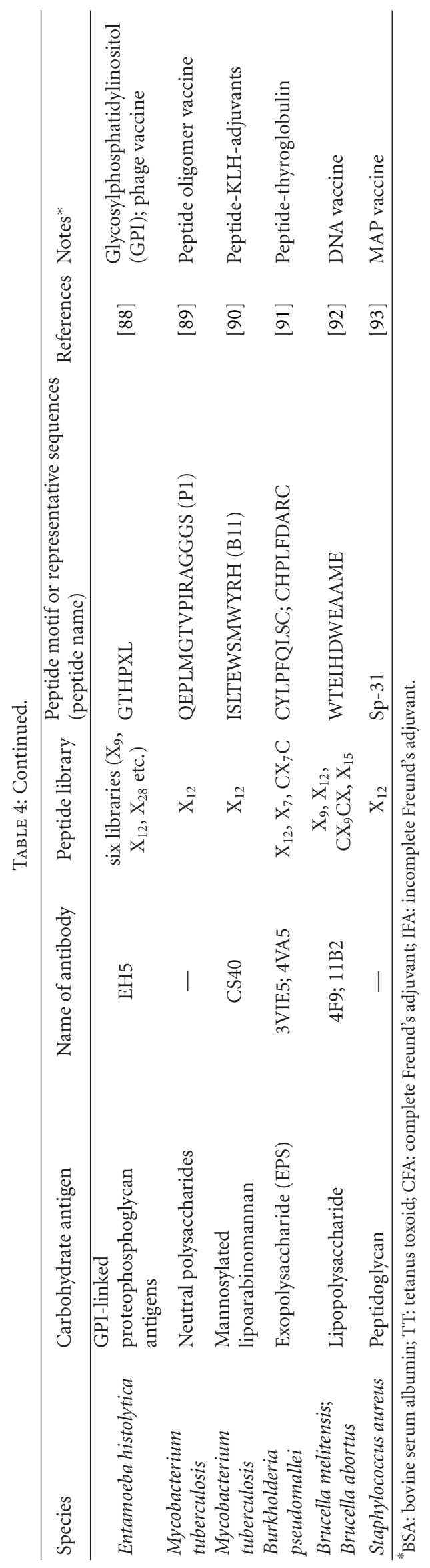


lung and spleen was completely inhibited by the intravenous injection of the peptide. Subsequently, WHW was found to be a minimal sequence that mimics the GD1 $\alpha$ structure [48]. To modify the liposome surface with the WHW peptide, the WHW tripeptide was conjugated to alkyl groups such as palmitoyl or stearoyl groups (Figure 3). Coating of liposomes with peptides is often performed in drug delivery systems. The WHW-modified liposomes inhibited the adhesion between RAW117-H10 cells and HSE cells.

Tryptophan/tyrosine-containing tripeptides (YPY for ConA, WRY for $\mathrm{sLe}^{\mathrm{X}(\mathrm{Y})}$, and WHW for GD1 $\alpha$ ) may comprise a key sequence that mimics oligosaccharide structure. Although $\mathrm{Gb}_{3}$ (Gal $\alpha 1-4 \mathrm{Gal} \beta 1-4 \mathrm{Glc}$ trisaccharide) is dissimilar to the disaccharide (Gal $\beta 1-3 \mathrm{GlcNAc} \beta)$ structure of $\mathrm{Lc}_{4}$ at the nonreducing terminus, Miura et al. identified a WHW-containing peptide (WHWTWLSEY) that mimics the $\mathrm{Gb}_{3}$ structure [60]. $\mathrm{Gb}_{3}$ is well known as a receptor for Shiga toxin (Stx). The $\mathrm{Gb}_{3}$-mimetic peptide showed neutralization activity against Stxs (Stx-1 and Stx-2) in a $\mathrm{HeLa}$ cell cytotoxicity assay. The binding affinity of the $\mathrm{Gb}_{3}-$ mimetic peptide for Stx-1 was also investigated by surface plasmon resonance analysis $\left(K_{\mathrm{d}}=1.4 \mathrm{nM}\right)$.

4.2. Oligosaccharide-Mimetic Peptides for Vaccination. The immunogenicity of oligosaccharides is weak because oligosaccharides are ubiquitous components of cell membranes in tissues throughout the human body. When antioligosaccharide antibodies are generated, they attack these tissues and cause the risk of autoimmune disease. For example, lipopolysaccharides of Campylobacter jejuni isolated from GBS patients contain ganglioside-like epitopes such as GM1, GM1b, GD1a, and GalNAc-GDla, and these epitopes induce Guillain-Barre syndrome [95]. However, this low immunogenicity interferes with the preparation of antioligosaccharide antibodies that are useful for the investigation of glycoconjugate function.

To improve the binding affinity, specificity and cytotoxicity of antibodies, oligosaccharide-mimetic peptides are applied as peptide mimotopes of carbohydrate antigens for vaccination (Figure 6). Oligosaccharide-mimetic peptides were identified by selection against $\operatorname{Le}^{\mathrm{X}(\mathrm{Y})}[34,35,37]$, $s e^{\mathrm{X}(\mathrm{Y})}[36,50]$, GD2 [36, 50-56], GD3 [36, 50, 59], lipooligosaccharide (LOS) [38, 39], $\beta$-1,2-oligomannoside [40], $N$-acetylglucosaminyl- $\beta 1,4-N$-acetylmuramyl-alanylD-isoglutamine (GMDP) [43], and high-mannose oligosaccharide $\left(\mathrm{Man}_{9} \mathrm{GlCNAc}_{2}\right.$ for HIV-1 gp120) [45]. The oligosaccharide-mimetic peptides were chemically synthesized and conjugated with adjuvant. To enhance the immunogenicity of the peptides, MAPs were prepared and resulted in dimeric, tetrameric, and octameric dendrimers (Figure 3). The peptide-adjuvant conjugates were vaccinated, with the adjuvants used being keyhole limpet hemocyanin (KLH) [39, 40, 53, 54], QS-21 [36, 50, 54], diphtheria toxoid (DT) [38], ovalbumin (OVA) [43], or very small size proteoliposomes (VSSP) [59] (Figure 6, Tables 2 and 3). In some cases, DNA vaccination was also performed $[55,56]$. The CMP-induced antibodies are able to bind to peptide mimotopes and carbohydrate antigens.

\section{CMPs against Polysaccharide-Binding Antibodies}

Most polysaccharide-mimetic peptides to be applied for vaccination are identified as peptide mimotopes of carbohydrate antigens (Figure 6). Capsular polysaccharides of microorganisms are carbohydrate antigens, and it is known that these polysaccharides cause meningoencephalitis in immunocompromised patients, particularly those with AIDS (polysaccharide from Cryptococcus neoformans), pneumonia and bacteremia (Streptococcus pneumoniae), bacterial meningitis (Neisseria meningitidis), cholera (Vibrio cholerae), tuberculosis (Mycobacterium tuberculosis), and so forth (Table 4). These peptide mimotopes are potential antigens for safe vaccination and are expected to produce highly cytotoxic antibodies.

The typical methodology for vaccination uses a CMPconjugated adjuvant. Valadon et al. identified CMPs that bind to anticryptococcal polysaccharide (glucuronoxylomannan, GXM) monoclonal antibody 2H1 [64]. The CMPs shared four motifs, for example, (E)TPXWM/LM/L and W/YXWM/LYE, and the dodecapeptide, GLQYTPSWMLVG (PA1) was found to bind $2 \mathrm{H} 1$ with a $K_{\mathrm{d}}$ of $295 \mathrm{nM}$ [64]. The three-dimensional structure of $2 \mathrm{H} 1$ has been solved in a complex with PA1 [65]. The peptide PA1 was improved by selection from a PA1-based sublibrary, which identified the peptide P206-1 (FGGETFTPDWMMEVAIDNE) [66]. The affinity of peptide 206-1 for $2 \mathrm{H} 1$ was 80 -fold higher than that of PA1 ( $K_{\mathrm{d}}$ of $\left.3.7 \mathrm{nM}\right)$. Immunization of mice with P206-1-tetanus toxoid (TT), but not PA1 or P601E (DGASYSWMYEA), induced an anti-GXM response [66, 67].

Although antibodies against the capsular polysaccharide of the same species (e.g., Neisseria meningitidis serogroup B) were used, the CMPs identified were different and shared no consensus motif $[73,75-80]$ (Table 4 ). This may be due to the different antibodies used (HmenB3, 9-2-L3, 30H12, Seam3, or 13D9), different primary peptide libraries $\left(\mathrm{CX}_{6} \mathrm{C}\right.$, $\mathrm{X}_{9}, \mathrm{CX}_{9} \mathrm{C}, \mathrm{X}_{12}$, or $\mathrm{X}_{15}$ ), or different selection conditions. Harris et al. also concluded that the CMPs identified by each antibody possessed distinct consensus motifs [72]. A variety of peptide-conjugating adjuvants such as KLH, TT, BSA, OVA, proteasome, and thyroglobulin have been used. In some cases, phage particles were directly used for vaccination $[80,86,88]$, and a high level of the $\operatorname{IgG}_{2 a}$ subtype in the response against CMPs was shown [80].

Theillet et al. clarified the structural mimicry of $O$ antigen oligosaccharide by CMPs [19]. Figure 5(c) shows a structural representation of the antibody-peptide complex in which the sugar chains were replaced by amino acids. Glc and GlcNAc were replaced by Tyr or Asp, and one or more hydrogen bonds are indicated. On the other hand, high-mannose oligosaccharide-mimic peptide (2G12-1 peptide) binds to a neighboring pocket of the oligosaccharide (Table 2) [45]. The binding site for the DVFYPYPYASGS peptide, which was selected against ConA, was different from the mannose/trimannosebinding site [26]. However, the peptide inhibits $\alpha$ mannopyranoside binding to ConA [25], indicating that this 
peptide shows functional mimicry rather than structural mimicry.

\section{Conclusion}

Anticarbohydrate antibodies are necessary for clarifying the biological functions of carbohydrates, the detection of carbohydrates during etiological diagnosis, and therapy for carbohydrate-related diseases $[7,96]$. Due to the difficulty in obtaining homogeneous glycoconjugates and carbohydratebinding proteins, phage display libraries have been applied for the identification of peptide mimotopes. In this paper, the selection of CMPs was classified according to the types of target carbohydrates. The first selection was performed against lectins, and then the selections were performed against anticarbohydrate antibodies. To apply the peptide mimotopes for vaccination, this methodology is becoming more widespread.

\section{Acknowledgment}

The preparation of this paper was supported in part by the Keio Gijuku Fukuzawa Memorial Fund for the Advancement of Education and Research.

\section{References}

[1] A. Varki, "Biological roles of oligosaccharides: all of the theories are correct," Glycobiology, vol. 3, no. 2, pp. 97-130, 1993.

[2] K. Takahashi, K. Tanabe, M. Ohnuki et al., "Induction of pluripotent stem cells from adult human fibroblasts by defined factors," Cell, vol. 131, no. 5, pp. 861-872, 2007.

[3] H. Lis and N. Sharon, "Lectins: carbohydrate-specific proteins that mediate cellular recognition," Chemical Reviews, vol. 98, no. 2, pp. 637-674, 1998.

[4] W. I. Weis and K. Drickamer, "Structural basis of lectincarbohydrate recognition," Annual Review of Biochemistry, vol. 65, pp. 441-473, 1996.

[5] G. A. Nores, R. D. Lardone, R. Comín, M. E. Alaniz, A. L. Moyano, and F. J. Irazoqui, "Anti-GM1 antibodies as a model of the immune response to self-glycans," Biochimica et Biophysica Acta, vol. 1780, no. 3, pp. 538-545, 2008.

[6] S. F. Slovin, S. J. Keding, and G. Ragupathi, "Carbohydrate vaccines as immunotherapy for cancer," Immunology and Cell Biology, vol. 83, no. 4, pp. 418-428, 2005.

[7] R. Kannagi and S. Hakomori, "A guide to monoclonal antibodies directed to glycotopes," Advances in Experimental Medicine and Biology, vol. 491, pp. 587-630, 2001.

[8] C.-H. Hsu, S.-C. Hung, C.-Y. Wu, and C.-H. Wong, "Toward automated oligosaccharide synthesis," Angewandte Chemie, vol. 50, no. 50, pp. 11872-11923, 2011.

[9] T. J. Boltje, T. Buskas, and G. J. Boons, "Opportunities and challenges in synthetic oligosaccharide and glycoconjugate research," Nature Chemistry, vol. 1, no. 8, pp. 611-622, 2009.

[10] S. I. Nishimura, "Combinatorial syntheses of sugar derivatives," Current Opinion in Chemical Biology, vol. 5, no. 3, pp. 325-335, 2001.

[11] S. M. Hancock, M. D. Vaughan, and S. G. Withers, "Engineering of glycosidases and glycosyltransferases," Current Opinion in Chemical Biology, vol. 10, no. 5, pp. 509-519, 2006.
[12] A. M. Daines, B. A. Maltman, and S. L. Flitsch, "Synthesis and modifications of carbohydrates, using biotransformations," Current Opinion in Chemical Biology, vol. 8, no. 2, pp. 106113, 2004.

[13] J. K. Scott, D. Loganathan, R. B. Easley, X. Gong, and I. J. Goldstein, "A family of concanavalin A-binding peptides from a hexapeptide epitope library," Proceedings of the National Academy of Sciences of the United States of America, vol. 89, no. 12, pp. 5398-5402, 1992.

[14] M. N. Fukuda, "Peptide-displaying phage technology in glycobiology," Glycobiology, vol. 22, no. 3, pp. 318-325, 2012.

[15] F. C. Dudak, I. H. Boyaci, and B. P. Orner, "The discovery of small-molecule mimicking peptides through phage display," Molecules, vol. 16, no. 1, pp. 774-789, 2011.

[16] R. Cortese, F. Felici, G. Galfre, A. Luzzago, P. Monaci, and A. Nicosia, "Epitope discovery using peptide libraries displayed on phage," Trends in Biotechnology, vol. 12, no. 7, pp. 262-267, 1994.

[17] T. Matsubara, A. Onishi, T. Saito et al., "Sialic acid-mimic peptides as hemagglutinin inhibitors for anti-influenza therapy," Journal of Medicinal Chemistry, vol. 53, no. 11, pp. 4441-4449, 2010.

[18] N. K. Sauter, J. E. Hanson, G. D. Glick et al., "Binding of influenza virus hemagglutinin to analogs of its cell-surface receptor, sialic acid: analysis by proton nuclear magnetic resonance spectroscopy and X-ray crystallography," Biochemistry, vol. 31, no. 40, pp. 9609-9621, 1992.

[19] F. X. Theillet, F. A. Saul, B. Vulliez-Le Normand et al., "Structural mimicry of $\mathrm{O}$-antigen by a peptide revealed in a complex with an antibody raised against Shigella flexneri serotype 2a," Journal of Molecular Biology, vol. 388, no. 4, pp. 839-850, 2009.

[20] G. P. Smith and V. A. Petrenko, "Phage display," Chemical Reviews, vol. 97, no. 2, pp. 391-410, 1997.

[21] G. P. Smith, "Filamentous fusion phage: novel expression vectors that display cloned antigens on the virion surface," Science, vol. 228, no. 4705, pp. 1315-1317, 1985.

[22] J. K. Scott and G. P. Smith, "Searching for peptide ligands with an epitope library," Science, vol. 249, no. 4967, pp. 386-390, 1990.

[23] B. Ru, J. Huang, P. Dai et al., "MimoDB: a new repository for mimotope data derived from phage display technology," Molecules, vol. 15, no. 11, pp. 8279-8288, 2010.

[24] J. Huang, B. Ru, P. Zhu et al., "MimoDB 2.0: a mimotope database and beyond," Nucleic Acids Research, vol. 40, no. D1, pp. D271-D277, 2012.

[25] K. R. Oldenburg, D. Loganathan, I. J. Goldstein, P. G. Schultz, and M. A. Gallop, "Peptide ligands for a sugar-binding protein isolated from a random peptide library," Proceedings of the National Academy of Sciences of the United States of America, vol. 89, no. 12, pp. 5393-5397, 1992.

[26] D. Jain, K. Kaur, B. Sundaravadivel, and D. M. Salunke, "Structural and functional consequences of peptide-carbohydrate mimicry: crystal structure of a carbohydrate-mimicking peptide bound to concanavalin A," Journal of Biological Chemistry, vol. 275, no. 21, pp. 16098-16102, 2000.

[27] D. L. Kooyman, S. B. Mcclellan, W. Parker et al., "Identification and characterization of a galactosyl peptide mimetic. Implications for use in removing xenoreactive anti-a gal antibodies," Transplantation, vol. 61, no. 6, pp. 851-855, 1996.

[28] J. Zhan, Z. Xia, L. Xu, Z. Yan, and K. Wang, "A peptide mimetic of Gal- $\alpha 1,3-\mathrm{Gal}$ is able to block human natural antibodies," Biochemical and Biophysical Research Communications, vol. 308, no. 1, pp. 19-22, 2003. 
[29] C. L. Martens, S. E. Cwirla, R. Y. W. Lee et al., "Peptides which bind to E-selectin and block neutrophil adhesion," Journal of Biological Chemistry, vol. 270, no. 36, pp. 21129-21136, 1995.

[30] M. N. Fukuda, C. Ohyama, K. Lowitz et al., "A peptide mimic of E-selectin ligand inhibits sialyl Lewis X-dependent lung colonization of tumor cells," Cancer Research, vol. 60, no. 2, pp. 450-456, 2000.

[31] L. Yu, P. S. Yu, E. Yee Yen Mui et al., "Phage display screening against a set of targets to establish peptide-based sugar mimetics and molecular docking to predict binding site," Bioorganic and Medicinal Chemistry, vol. 17, no. 13, pp. 4825-4832, 2009.

[32] L. L. Eggink and J. K. Hoober, "A biologically active peptide mimetic of N-acetylgalactosamine/galactose," BMC Research Notes, vol. 2, article 23, 2009.

[33] Z. Xu, G. S. Qian, Q. Li, Q. J. Feng, G. M. Wu, and K. L. Li, "Screening of mimetic peptides for CD14 binding site with LBP and antiendotoxin activity of mimetic peptide in vivo and in vitro," Inflammation Research, vol. 58, no. 1, pp. 45-53, 2009.

[34] R. Hoess, U. Brinkmann, T. Handel, and I. Pastan, "Identification of a peptide which binds to the carbohydrate-specific monoclonal antibody B3," Gene, vol. 128, no. 1, pp. 43-49, 1993.

[35] Q. Lou and I. Pastan, "A Lewis(y) epitope mimicking peptide induces anti-Lewis(y) immune responses in rabbits and mice," Journal of Peptide Research, vol. 53, no. 3, pp. 252-260, 1999.

[36] J. Qiu, P. Luo, K. Wasmund, Z. Steplewski, and T. KieberEmmons, "Towards the development of peptide mimotopes of carbohydrate antigens as cancer vaccines," Hybridoma, vol. 18, no. 1, pp. 103-112, 1999.

[37] N. Katagihallimath, A. Mehanna, D. Guseva, R. Kleene, and M. Schachner, "Identification and validation of a Lewisx glycomimetic peptide," European Journal of Cell Biology, vol. 89, no. 1, pp. 77-86, 2010.

[38] B. M. Charalambous and I. M. Feavers, "Peptide mimics elicit antibody responses against the outer-membrane lipooligosaccharide of group B Neisseria meningitidis," FEMS Microbiology Letters, vol. 191, no. 1, pp. 45-50, 2000.

[39] Y. Hou and X. X. Gu, "Development of peptide mimotopes of lipooligosaccharide from nontypeable Haemophilus influenzae as vaccine candidates," Journal of Immunology, vol. 170, no. 8, pp. 4373-4379, 2003.

[40] T. Jouault, C. Fradin, F. Dzierszinski et al., "Peptides that mimic Candida albicans-derived $\beta$-1,2-linked mannosides," Glycobiology, vol. 11, no. 8, pp. 693-701, 2001.

[41] M. Simon-Haldi, N. Mantei, J. Franke, H. Voshol, and M. Schachner, "Identification of a peptide mimic of the L2/HNK1 carbohydrate epitope," Journal of Neurochemistry, vol. 83, no. 6, pp. 1380-1388, 2002.

[42] J. Lang, J. Zhan, L. Xu, and Z. Yan, "Identification of peptide mimetics of xenoreactive $\alpha$-Gal antigenic epitope by phage display," Biochemical and Biophysical Research Communications, vol. 344, no. 1, pp. 214-220, 2006.

[43] A. G. Laman, A. O. Shepelyakovskaya, I. A. Berezin et al., "Identification of pentadecapeptide mimicking muramyl peptide," Vaccine, vol. 25, no. 15, pp. 2900-2906, 2007.

[44] G. Rojas, A. Pupo, M. Del Rosario Aleman, and N. Santiago Vispo, "Preferential selection of Cys-constrained peptides from a random phage-displayed library by anti-glucitollysine antibodies," Journal of Peptide Science, vol. 14, no. 11, pp. 1216-1221, 2008.

[45] A. Menendez, D. A. Calarese, R. L. Stanfield et al., "A peptide inhibitor of HIV-1 neutralizing antibody $2 \mathrm{G} 12$ is not a structural mimic of the natural carbohydrate epitope on gp120," FASEB Journal, vol. 22, no. 5, pp. 1380-1392, 2008.

[46] T. Taki, D. Ishikawa, H. Hamasaki, and S. Handa, "Preparation of peptides which mimic glycosphingolipids by using phage peptide library and their modulation on $\beta$-galactosidase activity," FEBS Letters, vol. 418, no. 1-2, pp. 219-223, 1997.

[47] D. Ishikawa, H. Kikkawa, K. Ogino, Y. Hirabayashi, N. Oku, and T. Taki, "GD1 $\alpha$-replica peptides functionally mimic GD1 $\alpha$, an adhesion molecule of metastatic tumor cells, and suppress the tumor metastasis," FEBS Letters, vol. 441, no. 1, pp. 20-24, 1998.

[48] M. Takikawa, H. Kikkawa, T. Asai et al., "Suppression of GD1 $\alpha$ ganglioside-mediated tumor metastasis by liposomalized WHW-peptide," FEBS Letters, vol. 466, no. 2-3, pp. 381384, 2000.

[49] J. X. Qiu and D. M. Marcus, "Use of peptide ligands to analyze the fine specificity of antibodies against asialo GM1," Journal of Neuroimmunology, vol. 100, no. 1-2, pp. 58-63, 1999.

[50] T. Kieber-Emmons, P. Luo, J. Qiu, T. Y. Chang, M. BlaszczykThurin, and Z. Steplewski, "Vaccination with carbohydrate peptide mimotopes promotes anti-tumor responses," Nature Biotechnology, vol. 17, no. 7, pp. 660-665, 1999.

[51] A. Wondimu, T. Zhang, T. Kieber-Emmons et al., "Peptides mimicking GD2 ganglioside elicit cellular, humoral and tumor-protective immune responses in mice," Cancer Immunology, Immunotherapy, vol. 57, no. 7, pp. 1079-1089, 2008.

[52] E. Förster-Waldl, A. B. Riemer, A. K. Dehof et al., "Isolation and structural analysis of peptide mimotopes for the disialoganglioside GD2, a neuroblastoma tumor antigen," Molecular Immunology, vol. 42, no. 3, pp. 319-325, 2005.

[53] A. B. Riemer, E. Förster-Waldl, K. H. Brämswig et al., "Induction of IgG antibodies against the GD2 carbohydrate tumor antigen by vaccination with peptide mimotopes," European Journal of Immunology, vol. 36, no. 5, pp. 1267-1274, 2006.

[54] M. Bleeke, S. Fest, N. Huebener et al., "Systematic amino acid substitutions improved efficiency of GD2-peptide mimotope vaccination against neuroblastoma," European Journal of Cancer, vol. 45, no. 16, pp. 2915-2921, 2009.

[55] E. Bolesta, A. Kowalczyk, A. Wierzbicki et al., "DNA vaccine expressing the mimotope of GD2 ganglioside induces protective GD2 cross-reactive antibody responses," Cancer Research, vol. 65, no. 8, pp. 3410-3418, 2005.

[56] A. Wierzbicki, M. Gil, M. Ciesielski et al., "Immunization with a mimotope of GD2 ganglioside induces CD8+ T cells that recognize cell adhesion molecules on tumor cells," Journal of Immunology, vol. 181, no. 9, pp. 6644-6653, 2008.

[57] I. Horwacik, D. Czaplicki, K. Talarek et al., "Selection of novel peptide mimics of the GD2 ganglioside from a constrained phage-displayed peptide library," International Journal of Molecular Medicine, vol. 19, no. 5, pp. 829-839, 2007.

[58] I. Horwacik, M. Kurciński, M. Bzowska et al., "Analysis and optimization of interactions between peptides mimicking the GD2 ganglioside and the monoclonal antibody 14G2a," International Journal of Molecular Medicine, vol. 28, no. 1, pp. 47-57, 2011.

[59] I. Popa, D. Ishikawa, M. Tanaka, K. Ogino, J. Portoukalian, and T. Taki, "GD3-replica peptides selected from a phage peptide library induce a GD3 ganglioside antibody response," FEBS Letters, vol. 580, no. 5, pp. 1398-1404, 2006.

[60] Y. Miura, A. Sakaki, M. Kamihira, S. Iijima, and K. Kobayashi, "A globotriaosylceramide (Gb3Cer) mimic peptide isolated from phage display library expressed strong neutralization to 
Shiga toxins," Biochimica et Biophysica Acta, vol. 1760, no. 6, pp. 883-889, 2006.

[61] A. Perez, E. S. Mier, N. S. Vispo, A. M. Vazquez, and R. P. Rodríguez, "A monoclonal antibody against NeuGc- containing gangliosides contains a regulatory idiotope involved in the interaction with B and T cells," Molecular Immunology, vol. 39, no. 1-2, pp. 103-112, 2002.

[62] A. López-Requena, C. M. De Acosta, E. Moreno et al., "Gangliosides, Ab1 and Ab2 antibodies. I. Towards a molecular dissection of an idiotype-anti-idiotype system," Molecular Immunology, vol. 44, no. 4, pp. 423-433, 2007.

[63] J. H. Youn, H. J. Myung, A. Liav et al., "Production and characterization of peptide mimotopes of phenolic glycolipidI of Mycobacterium leprae," FEMS Immunology and Medical Microbiology, vol. 41, no. 1, pp. 51-57, 2004.

[64] P. Valadon, G. Nussbaum, L. F. Boyd, D. H. Margulies, and M. D. Scharff, "Peptide libraries define the fine specificity of anti-polysaccharide antibodies to Cryptococcus neoformans," Journal of Molecular Biology, vol. 261, no. 1, pp. 11-22, 1996.

[65] A. C. M. Young, P. Valadon, A. Casadevall, M. D. Scharff, and J. C. Sacchettini, "The three-dimensional structures of a polysaccharide binding antibody to Cryptococcus neoformans and its complex with a peptide from a phage display library: implications for the identification of peptide mimotopes," Journal of Molecular Biology, vol. 274, no. 4, pp. 622-634, 1997.

[66] D. O. Beenhouwer, R. J. May, P. Valadon, and M. D. Scharff, "High affinity mimotope of the polysaccharide capsule of Cryptococcus neoformans identified from an evolutionary phage peptide library," Journal of Immunology, vol. 169, no. 12, pp. 6992-6999, 2002.

[67] P. Valadon, G. Nussbaum, J. Oh, and M. D. Scharff, "Aspects of antigen mimicry revealed by immunization with a peptide mimetic of Cryptococcus neoformans polysaccharide," Journal of Immunology, vol. 161, no. 4, pp. 1829-1836, 1998.

[68] S. H. Pincus, M. J. Smith, H. J. Jennings, J. B. Burritt, and P. M. Glee, "Peptides that mimic the group B streptococcal type III capsular polysaccharide antigen," Journal of Immunology, vol. 160, no. 1, pp. 293-298, 1998.

[69] G. B. Lesinski, S. L. Smithson, N. Srivastava, D. Chen, G. Widera, and M. A. J. Westerink, "A DNA vaccine encoding a peptide mimic of Streptococcus pneumoniae serotype 4 capsular polysaccharide induces specific anti-carbohydrate antibodies in Balb/c mice," Vaccine, vol. 19, no. 13-14, pp. 1717-1726, 2001

[70] U. K. Buchwald, A. Lees, M. Steinitz, and L. A. Pirofski, "A peptide mimotope of type 8 pneumococcal capsular polysaccharide induces a protective immune response in mice," Infection and Immunity, vol. 73, no. 1, pp. 325-333, 2005.

[71] C. M. Smith, C. L. Passo, A. Scuderi et al., "Peptide mimics of two pneumococcal capsular polysaccharide serotypes $(6 \mathrm{~B}$ and $9 \mathrm{~V})$ protect mice from a lethal challenge with Streptococcus pneumoniae," European Journal of Immunology, vol. 39, no. 6, pp. 1527-1535, 2009.

[72] S. L. Harris, L. Craig, J. S. Mehroke et al., "Exploring the basis of peptide-carbohydrate crossreactivity: evidence for discrimination by peptides between closely related anticarbohydrate antibodies," Proceedings of the National Academy of Sciences of the United States of America, vol. 94, no. 6, pp. 2454-2459, 1997.

[73] Y. Wu, Q. Zhang, D. Sales, A. E. Bianco, and A. Craig, "Vaccination with peptide mimotopes produces antibodies recognizing bacterial capsular polysaccharides," Vaccine, vol. 28, no. 39, pp. 6425-6435, 2010.
[74] M. C. Grothaus, N. Srivastava, S. L. Smithson et al., "Selection of an immunogenic peptide mimic of the capsular polysaccharide of Neisseria meningitidis serogroup A using a peptide display library," Vaccine, vol. 18, no. 13, pp. 1253-1263, 2000.

[75] I. Park, I. H. Choi, S. J. Kim, and J. S. Shin, "Peptide mimotopes of Neisseria meningitidis group B capsular polysaccharide," Yonsei Medical Journal, vol. 45, no. 4, pp. 755-758, 2004.

[76] V. Lauvrak, G. Berntzen, U. Heggelund et al., "Selection and characterization of cyclic peptides that bind to a monoclonal antibody against meningococcal L3,7,9 lipopolysaccharides," Scandinavian Journal of Immunology, vol. 59, no. 4, pp. 373384, 2004.

[77] P. Torregrossa, L. Buhl, M. Bancila et al., "Selection of poly$\alpha$ 2,8-sialic acid mimotopes from a random phage peptide library and analysis of their bioactivity," Journal of Biological Chemistry, vol. 279, no. 29, pp. 30707-30714, 2004.

[78] P. Marino, J. C. Norreel, M. Schachner, G. Rougon, and M. C. Amoureux, "A polysialic acid mimetic peptide promotes functional recovery in a mouse model of spinal cord injury," Experimental Neurology, vol. 219, no. 1, pp. 163-174, 2009.

[79] C. Lo Passo, A. Romeo, I. Pernice et al., "Peptide mimics of the group B meningococcal capsule induce bactericidal and protective antibodies after immunization," Journal of Immunology, vol. 178, no. 7, pp. 4417-4423, 2007.

[80] T. Menéndez, N. F. Santiago-Vispo, Y. Cruz-Leal et al., "Identification and characterization of phage-displayed peptide mimetics of Neisseria meningitidis serogroup B capsular polysaccharide," International Journal of Medical Microbiology, vol. 301, no. 1, pp. 16-25, 2011.

[81] D. M. Prinz, S. L. Smithson, and M. A. J. Westerink, "Two different methods result in the selection of peptides that induce a protective antibody response to Neisseria meningitidis serogroup C," Journal of Immunological Methods, vol. 285, no. 1, pp. 1-14, 2004.

[82] G. R. Moe and D. M. Granoff, "Molecular mimetics of Neisseria meningitidis serogroup B polysaccharide," International Reviews of Immunology, vol. 20, no. 2, pp. 201-220, 2001.

[83] S. Falklind-Jerkérus, F. Felici, C. Cavalieri et al., "Peptides mimicking Vibrio cholerae O139 capsular polysaccharide elicit protective antibody response," Microbes and Infection, vol. 7, no. 15, pp. 1453-1460, 2005.

[84] M. N. Dharmasena, D. A. Jewell, and R. K. Taylor, "Development of peptide mimics of a protective epitope of Vibrio cholerae Ogawa $\mathrm{O}$-antigen and investigation of the structural basis of peptide mimicry," Journal of Biological Chemistry, vol. 282, no. 46, pp. 33805-33816, 2007.

[85] M. N. Dharmasena, S. J. Krebs, and R. K. Taylor, "Characterization of a novel protective monoclonal antibody that recognizes an epitope common to Vibrio cholerae Ogawa and Inaba serotypes," Microbiology, vol. 155, no. 7, pp. 2353-2364, 2009.

[86] A. Phalipon, A. Folgori, J. Arondel et al., "Induction of anticarbohydrate antibodies by phage library-selected peptide mimics," European Journal of Immunology, vol. 27, no. 10, pp. 2620-2625, 1997.

[87] M. Geiser, D. Schultz, A. Le Cardinal, H. Voshol, and C. García-Echeverría, "Identification of the human melanomaassociated chondroitin sulfate proteoglycan antigen epitope recognized by the antitumor monoclonal antibody 763.74 from a peptide phage library," Cancer Research, vol. 59, no. 4, pp. 905-910, 1999.

[88] H. Melzer, P. Fortugno, E. Mansouri et al., "Antigenicity and immunogenicity of phage library-selected peptide mimics of 
the major surface proteophosphoglycan antigens of Entamoeba histolytica," Parasite Immunology, vol. 24, no. 6, pp. 321-328, 2002.

[89] G. Gevorkian, E. Segura, G. Acero et al., "Peptide mimotopes of Mycobacterium tubercolosis carbohydrate immunodeterminants," Biochemical Journal, vol. 387, no. 2, pp. 411-417, 2005.

[90] A. Barenholz, A. H. Hovav, Y. Fishman, G. Rahav, J. M. Gershoni, and H. Bercovier, "A peptide mimetic of the mycobacterial mannosylated lipoarabinomannan: characterization and potential applications," Journal of Medical Microbiology, vol. 56, no. 5, pp. 579-586, 2007.

[91] J. B. Legutki, M. Nelson, R. Titball, D. R. Galloway, A. Mateczun, and L. W. Baillie, "Analysis of peptide mimotopes of Burkholderia pseudomallei exopolysaccharide," Vaccine, vol. 25, no. 45, pp. 7796-7805, 2007.

[92] C. Beninati, M. Garibaldi, C. L. Passo et al., "Immunogenic mimics of Brucella lipopolysaccharide epitopes," Peptides, vol. 30, no. 10, pp. 1936-1939, 2009.

[93] Y. Chen, B. Liu, D. Yang et al., "Peptide mimics of peptidoglycan are vaccine candidates and protect mice from infection with Staphylococcus aureus," Journal of Medical Microbiology, vol. 60, no. 7, pp. 995-1002, 2011.

[94] J. P. Tam, "Synthetic peptide vaccine design: synthesis and properties of a high-density multiple antigenic peptide system," Proceedings of the National Academy of Sciences of the United States of America, vol. 85, no. 15, pp. 5409-5413, 1988.

[95] N. Yuki, "Infectious origins of, and molecular mimicry in, Guillain-Barré and Fisher syndromes," Lancet Infectious Diseases, vol. 1, no. 1, pp. 29-37, 2001.

[96] T. Feizi, "Demonstration by monoclonal antibodies that carbohydrate structures of glycoproteins and glycolipids are onco-developmental antigens," Nature, vol. 314, no. 6006, pp. 53-57, 1985. 

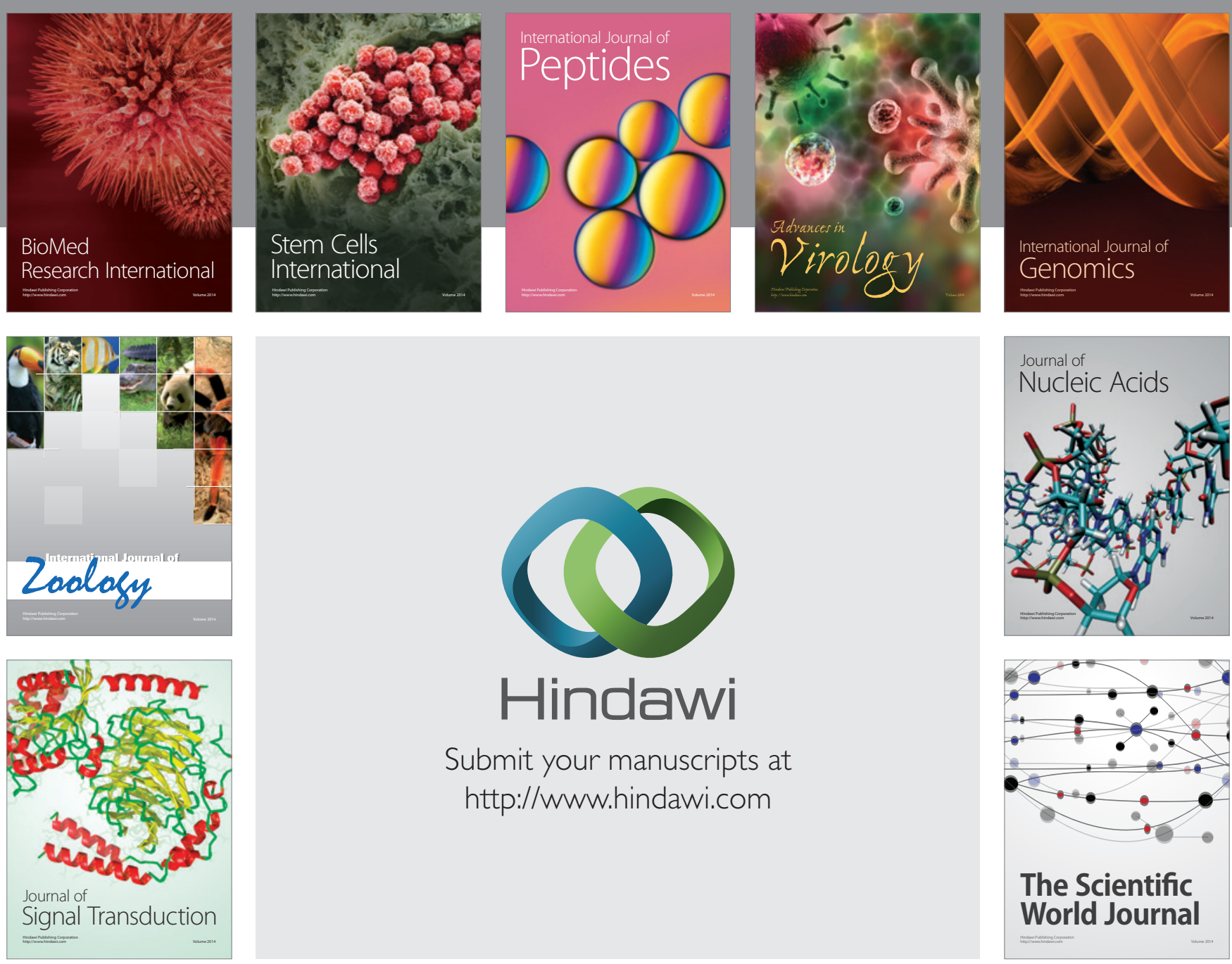

Submit your manuscripts at

http://www.hindawi.com
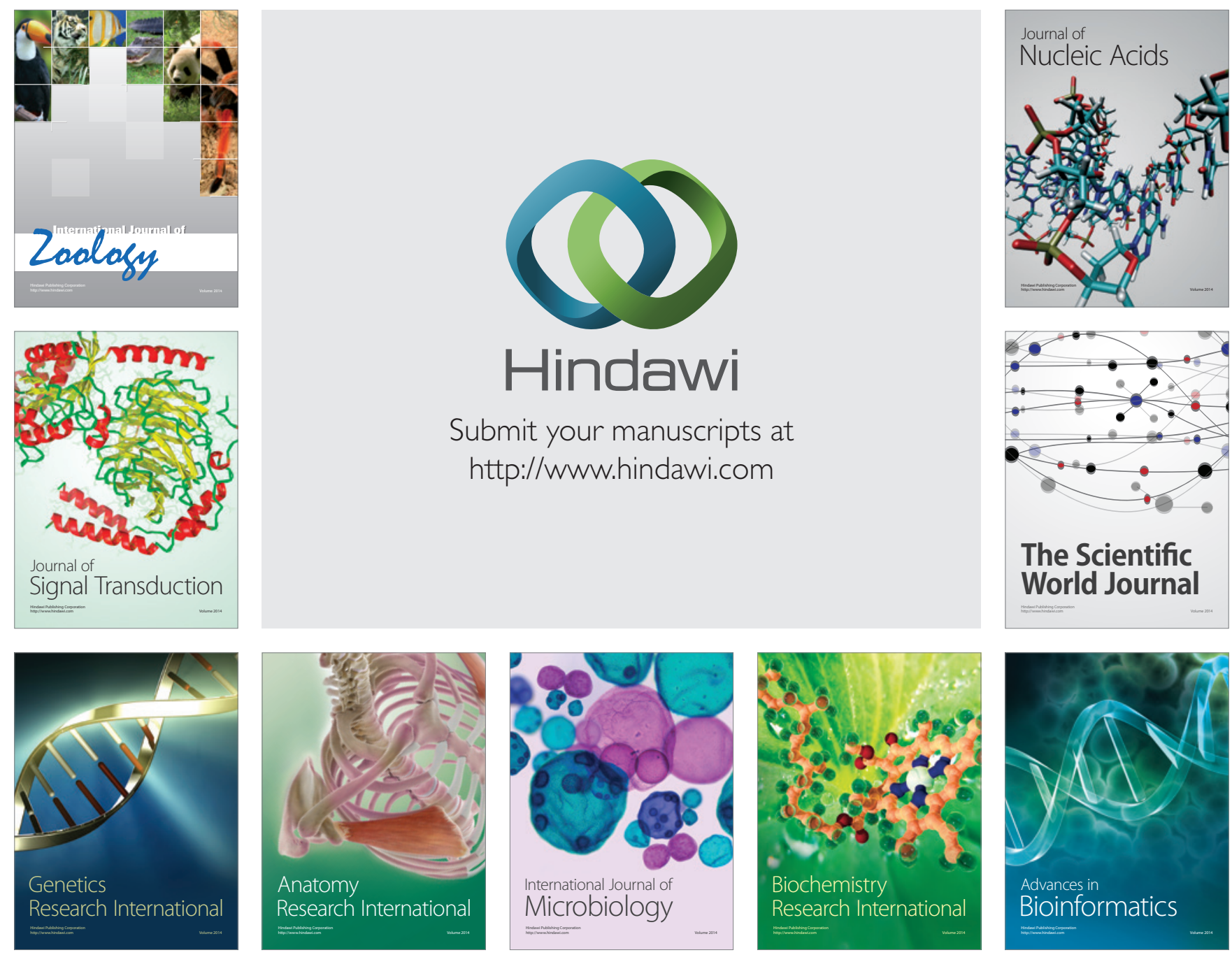

The Scientific World Journal
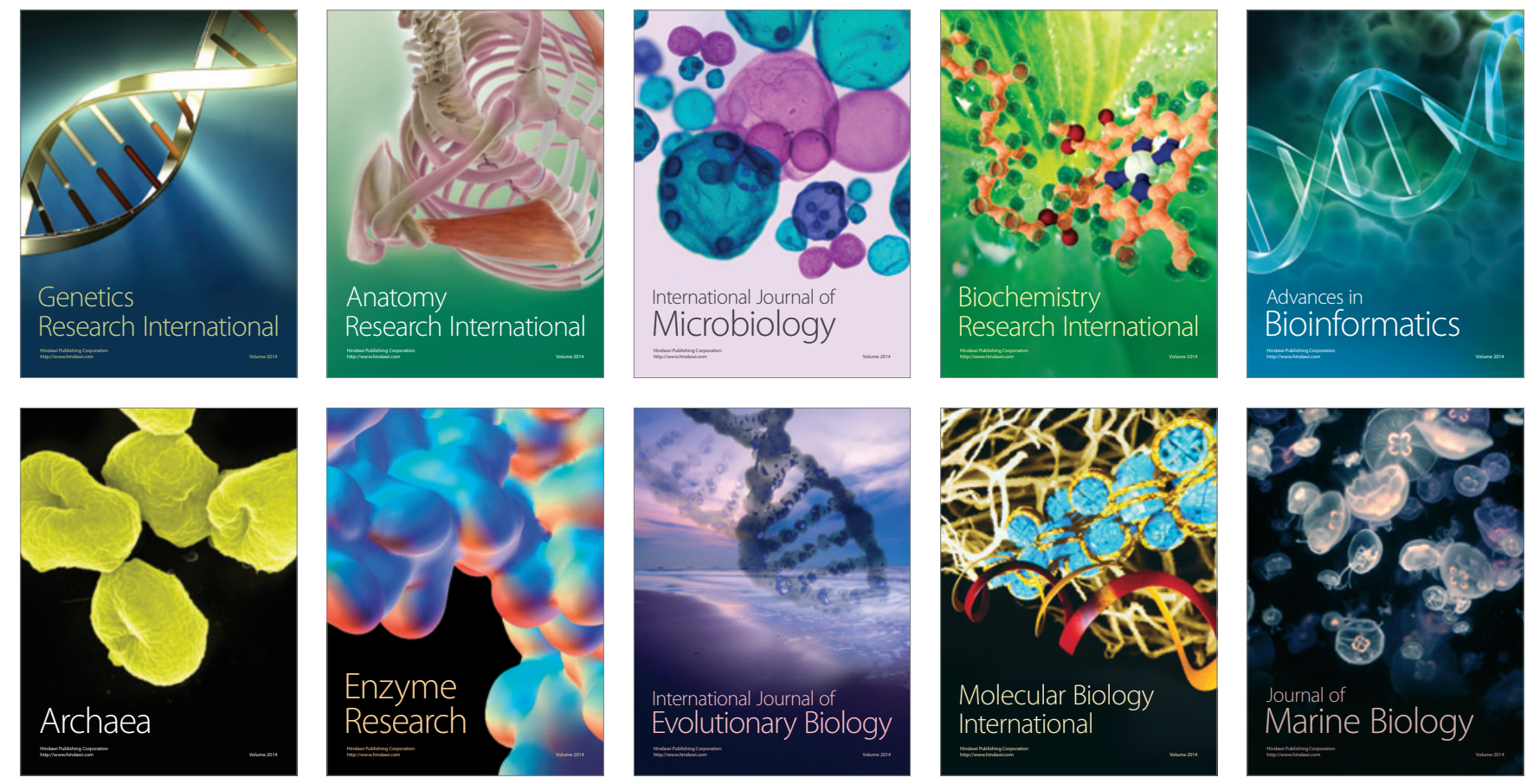